\title{
Microbiological Quality of Eight Wild Edible Mushroom Species from Turkey
}

\author{
Bülent Ergönül ${ }^{1 *}$, Fatih Kalyoncu², Ilgaz Akata ${ }^{3}$ \\ ${ }^{1}$ Department of Food Engineering, Faculty of Engineering, Manisa Celal Bayar University, Manisa, Turkey \\ ${ }^{2}$ Department of Biology, Faculty of Science and Letters, Manisa Celal Bayar University, Manisa, Turkey \\ ${ }^{3}$ Department of Biology, Faculty of Science, Ankara University, Ankara, Turkey \\ *bulent.ergonul@hotmail.com
}

Received: 29 August 2018

Accepted: 31 October 2018

DOI: $10.18466 /$ cbayarfbe. 455754

\begin{abstract}
In this study, it was aimed to determine the microbiological attributes of 8 wild edible mushrooms (Agrocybe cylindracea, Amanita cecilae, Boletus reticulatus, Coprinus comatus, Cantharellus cibarius, Lactarius deliciosus, Suillus collinitus and Tricholoma myomyces) collected from different parts of Anatolia, Turkey. In order to determine the microbiological and hygienic situation, E.coli O157:H7, Listeria monocytogenes, yeast and molds, total mesophilic aerobic bacteria count, total coliforms, lactic acid bacteria, Salmonella spp., Staphylococcus aureus and Clostridium botulinum were investigated for mushroom species. According to obtained data, microbiological and hygienic characteristics of wild edible mushrooms are acceptable.
\end{abstract}

Keywords: Wild edible mushroom, Anatolia, microbiological quality, food safety

\section{Introduction}

Consumption amounts of mushrooms is slightly increasing in recent years [1]. For both their nutritional value and their organoleptic attributes, they are commonly and traditionally used in Turkish cuisine.

Mushrooms are widely distributed all over the world and some of these mushrooms are also known for their antimicrobiological and antioxidant characteristics in both food and drug industry [2, 3].

Fresh mushrooms have high moisture content and water activity, so microorganisms can use this media for microbiological growth [4]. Also another important factor supporting the microbiological growth is the neutral $\mathrm{pH}$ of mushroom [5]. Because of this adverse effects, the shelf life of fresh mushrooms is rather limited, especially a few days [6].

Harvest, handling, storage and shipping of mushrooms are generally performed at ambient temperature [4]. It can also be underlined that ambient temperature is another important factor supporting microbiological growth.

It is important to determine the microbiological attributes of mushrooms as well as other quality parameters like texture, color etc. Because majority of the commercial mushrooms are marketed just after packaging without any washing and cleaning facilities.
Up to our knowledge, there is rather limited scientific information reported in terms of wild edible mushrooms, their microbiological attributes and food safety. In this research it was aimed to determine the microbiological characteristics of eight different species of wild edible mushrooms collected from different parts of Anatolia, Turkey.

\section{Materials and Methods \\ 2.1 Materials}

Eight different species of wild edible mushrooms (Agrocybe cylindracea, Amanita cecilae, Boletus reticulatus, Coprinus comatus, Cantharellus cibarius, Lactarius deliciosus, Suillus collinitus and Tricholoma myomyces) were collected from different parts of Anatolia.

Information regarding the geographical distribution of these species s given as Table 1 below. All mushroom species were collected regarding the Table 1 and deposited in Biology Department of Ankara University, Ankara. Wild edible mushroom species were transferred into microbiology laboratory under refrigeration and immediately taken into analysis on the same day under refrigerated conditions to determine the microbiological quality and safety. 
Table 1. Wild edible mushroom species geographical distribution.

\begin{tabular}{lccc}
\hline Species & Coordinate & Attitude (m) & Fungarium Number \\
\hline Agrocybe cylindracea & N 39 56 - E 32 49 & 860 & AKATA 1037 \\
Amanita cecilae & N 40 53 - E 39 50 & 850 & AKATA 3037 \\
Boletus reticulatus & N 41 03 - E 33 41 & 1880 & AKATA 1091 \\
Coprinus comatus & N 39 56 - E 32 49 & 860 & AKATA 2113 \\
Cantharellus cibarius & N 40 53 - E 39 50 & 850 & AKATA 3011 \\
Lactarius deliciosus & N 40 36 - E 31 17 & 1340 & AKATA 2434 \\
Suillus collinitus & N 41 04 - E 33 44 & 1780 & AKATA 1068 \\
Tricholoma myomyces & N 41 08 - E 33 50 & 1200 & AKATA 1561 \\
\hline
\end{tabular}

\subsection{Methods}

Mushrooms were microbiologically analyzed according to standard methods given in Table 2.
Findings were evaluated by using SAS Statistical programme in order the find the importance of the differences (SAS, 2001).

Table 2. Methods used for microbiological analysis of wild edible mushrooms.

\begin{tabular}{|c|c|c|}
\hline Microorganism / Code & Methodology & Description \\
\hline Total aerobic mesophilic bacteria (TAMB) & [7] & Colony-count technique at $30 \circ \mathrm{C}$ \\
\hline Lactic acid bacteria (LAB) & [4] & Colony-count technique at $30 \circ \mathrm{C}$ \\
\hline Yeasts and molds (YM) & [4] & Colony-count technique at $25 \circ \mathrm{C}$ \\
\hline Total coliforms (TC) & [8] & Colony-count technique at $37{ }^{\circ} \mathrm{C}$ \\
\hline E. coli $\mathrm{O} 157: \mathrm{H} 7(\mathrm{EC})$ & [4] & $\begin{array}{l}\text { Horizontal method for the detection of } \\
\text { Escherichia coli } \mathrm{O} 157\end{array}$ \\
\hline L. monocytogenes (LM) & [9] & $\begin{array}{l}\text { Horizontal method for the detection and } \\
\text { enumeration of Listeria monocytogenes }\end{array}$ \\
\hline Salmonella spp. (SAL) & [4] & $\begin{array}{l}\text { Horizontal method for the detection of } \\
\text { Salmonella spp. }\end{array}$ \\
\hline S.aureus (SA) & [4] & $\begin{array}{l}\text { Technique using Baird-Parker agar } \\
\text { medium, incubation at } 37 \circ \mathrm{C}\end{array}$ \\
\hline Clostridium botulinum & [10] & Anaerobic incubation, $35 \circ \mathrm{C}$ \\
\hline
\end{tabular}

\section{Results and Discussion}

Microbiological attributes of 8 wild edible mushroom species were given as Table 3 .

Table 3. Average microbiological attributes of 8 wild edible mushroom species $(\log \mathrm{cfu} / \mathrm{g})$.

\begin{tabular}{|c|c|c|c|c|c|c|c|c|c|}
\hline Species & TAMB & LAB & YM & TC & EC & LM & SAL & SA & $\mathrm{CB}$ \\
\hline $\begin{array}{l}\text { Agrocybe } \\
\text { cylindracea }\end{array}$ & $8.4 \pm 1.2 b^{*}$ & $1.7 \pm 0.2 b$ & $2.6 \pm 1.2$ & $0.3 \pm 0.2$ & ND & ND & ND & ND & ND \\
\hline $\begin{array}{l}\text { Amanita } \\
\text { cecilae }\end{array}$ & $7.4 \pm 2.1 \mathrm{c}$ & $2.1 \pm 0.6 \mathrm{a}$ & $2.5 \pm 1.4$ & ND & ND & ND & ND & ND & ND \\
\hline $\begin{array}{l}\text { Boletus } \\
\text { reticulatus }\end{array}$ & $9.2 \pm 1.7 \mathrm{a}$ & $2.2 \pm 0.6 \mathrm{a}$ & $2.4 \pm 0.8$ & $0.6 \pm 0.1$ & ND & ND & ND & ND & ND \\
\hline $\begin{array}{l}\text { Coprinus } \\
\text { comatus }\end{array}$ & $6.8 \pm 1.3 \mathrm{c}$ & $1.4 \pm 0.2 b$ & $2.2 \pm 0.4$ & $1.2 \pm 0.6$ & ND & ND & ND & ND & ND \\
\hline $\begin{array}{l}\text { Cantharellus } \\
\text { cibarius }\end{array}$ & $7.6 \pm 1.2$ & $1.6 \pm 0.2 b$ & $1.9 \pm 0.6$ & ND & ND & ND & ND & ND & ND \\
\hline $\begin{array}{l}\text { Lactarius } \\
\text { deliciosus }\end{array}$ & $8.2 \pm 1.4 b$ & $1.8 \pm 0.8 b$ & $3.3 \pm 0.6$ & ND & ND & ND & ND & ND & ND \\
\hline $\begin{array}{l}\text { Suillus } \\
\text { collinitus }\end{array}$ & $8.8 \pm 1.0 \mathrm{~b}$ & $2.2 \pm 0.4 \mathrm{a}$ & $2.8 \pm 0.6$ & ND & ND & ND & ND & ND & ND \\
\hline $\begin{array}{l}\text { Tricholoma } \\
\text { myomyces }\end{array}$ & $6.9 \pm 1.1 \mathrm{c}$ & $2.4 \pm 0.6 \mathrm{a}$ & $2.6 \pm 0.2$ & $1.4 \pm 0.4$ & ND & ND & ND & ND & ND \\
\hline
\end{tabular}

${ }^{*}$ Counts with different letters are statistically different from each other $(\mathrm{P}<0.05)$. 
As seen from Table 3, average total aerobic mesophilic bacteria, lactic acid bacteria, yeast and mold, total coliforms, E.coli O157:H7, Listeria monocytogenes, Salmonella spp. and Staphylococcus aureus counts of eight different wild edible mushroom species were enumerated.

Highest average TAMB count (9.2 log $\mathrm{cfu} / \mathrm{g})$ was determined for Boletus reticulatus, whereas the lowest one $(6.8 \mathrm{log} \mathrm{cfu} / \mathrm{g})$ was for the Coprinus comatus. In general, for all mushroom species, TAMB counts were over $6.0 \log \mathrm{cfu} / \mathrm{g}$.

TAMB counts were enumerated as $8.4 \mathrm{log} \mathrm{cfu} / \mathrm{g}, 7.4 \mathrm{log}$ cfu/g, $7.6 \log \mathrm{cfu} / \mathrm{g}, 8.2 \mathrm{log} \mathrm{cfu} / \mathrm{g}, 8.8 \mathrm{log} \mathrm{cfu} / \mathrm{g}$ and 6.9 $\log \mathrm{cfu} / \mathrm{g}$ for Agrocybe cylindracea, Amanita cecilae, Cantharellus cibarius, Lactarius deliciosus, Suillus collinitus and Tricholoma myomyces respectively. TMAB count of Boletus reticulatus is statistically higher than the other mushroom samples $(\mathrm{P}<0.05)$.

According to Venturini et al. [4], TAMB counts of wide edible mushrooms from Spain were among $4.4 \mathrm{log} \mathrm{cfu} / \mathrm{g}$ and $9.4 \log \mathrm{cfu} / \mathrm{g}$. The majority of the species had counts ranging among $6 \log \mathrm{cfu} / \mathrm{g}$ and $8 \log \mathrm{cfu} / \mathrm{g}$. Findings of Venturini et al. [4] are quite similar to our results.

Lactic acid bacteria counts of mushroom species were among $1.4 \mathrm{log} \mathrm{cfu} / \mathrm{g}$ and $2.4 \mathrm{log} \mathrm{cfu} / \mathrm{g}$.The highest LAB counts were enumerated for the samples Tricholoma myomyces (2.4 log cfu/g), Suillus collinitus (2.2 log cfu/g), Boletus reticulatus (2.1 log cfu/g) and Amanita cecilae $(2.1 \log \mathrm{cfu} / \mathrm{g}$ ) respectively. On the other hand, the highest yeast and mold count was counted for the mushroom Lactarius deliciosus (3.3 log cfu/g).

Venturini et al. [4] reported that the average lactic acid bacteria count of wild mushroom species from Spain was $2.1 \mathrm{log} \mathrm{cfu} / \mathrm{g}$. Also they declared that average yeast and mold count of the same samples was $3.7 \mathrm{log} \mathrm{cfu} / \mathrm{g}$ which is quite similar to our findings.

E.coli O157:H7, Listeria monocytogenes, Salmonella spp. and Staphylococcus aureus were not detected for any of the mushroom species. This was found quite satisfactory in terms of microbiological quality and safety. For four samples $(50 \%)$ total coliforms were determined at low amounts (0.3-1.4 log cfu/g).

Also, Clostridium botulinum was not detected in any of the samples which takes an important role while processing mushrooms into canned foods.

\section{Conclusion}

Since in any of the samples E.coli O157:H7, Salmonella spp., Listeria monocytogenes and Staphylococcus aureus were not detected, according to microbiological analysis results of the wild edible mushroom samples, it can be concluded that the microbiological safety of the samples are acceptable. No pathogens were isolated.
Because of low total coliforms count, an improvement in hygienic situation of these mushrooms might be suggested.

\section{References}

1. Amsterdam, J., Opperhuizen, A., den Brink W. Harm potential of magic mushroom use: A review. Regulatory Toxicology and Pharmacology, 2011, 59, 423-429.

2. Akata, I., Ergönül, B., Kalyoncu, F. Chemical compositions an antioxidant activities of 16 wild edible mushroom species grown in Anatolia. International Journal of Pharmacology, 2012, DOI:10.3923/ijp.2012.

3. Kosanic, M., Raknovic, R.N., Dasic, M. Antioxidant and antimicrobial properties of mushrooms. Bulgarian Journal of Agricultural Science, 2013, 19(5), 1040-1046

4. Venturini, M.E., Ryes, J.E., Rivera, C.S., Oria, R., Blanco, D. Microbiological quality and safety of fresh cultivated and wild mushrooms commercialized in Spain. Food Microbiology, 2011, $28,8,1492-1498$

5. SAS, 2001. Statistical analysis package programme. Purdue University, Purdure, USA

6. Martinez-Carrera, D., Sobal, M., Aguilar, A., Navarro, M., Bonilla M., Larquee-Saavedra, A. Canning technology as an alternative for management and conservation of wild edible mushrooms in Mexico. Micologia Neotropical Aplicada, 1998, 11, 35-51.

7. Brennan, M.H., Gormley, T.R. 1998. Extending the Shelf Life of fresh sliced mushrooms. The National Food Center, Research Report No:2.

8. Donzellini, M., Lorini, C., Palazzoni, S., Becciolini, M., Cibecchini, A., Talini, M., Bonaccorsi, G. Research on mesophilic aerobic microorganisms and Enterobacteriaceae in cultivated and commercialized Agaricus bisporus. Ann Ig, 2018, 30, 104-111.

9. Ajis, A.H., Chong, L.J., Tan, Y.S., Chai, L.C. 2017. Microbial food safety assessment of dried edible mushrooms. Journal für Verbraucherschutz und Lebensmittelsicherheit, 2017, 12(3), DOI: 10.1007/s00003-017-1117-x.

10. Chen, M., Cheng, J., Wu, Q., Zhang, J., Chen, Y, Zheng, H., Ye, Q., Wu, S., Cai, S., Wang, J., Ding, Y. Prevalence, Potential Virulence, and Genetic Diversity of Listeria monocytogenes Isolates From Edible Mushrooms in Chinese Markets. Frontiers in Microbiology, 2018, 9:1711 doi: 10.3389/fmicb.2018.01711

11. Anonymous, 2005. Merck Gıda Mikrobiyolojisi Uygulamaları. Ed A. K. Halkman. Başak Matbaacılık Ltd. Şti., Ankara, 358 sayfa. 